\title{
Administration and Judicial Review of Economic Controls
}

In connection with the initiation of Phase II of the Nixon Administration's wage and price control program, the President proposed to Congress in October, 1971, that it extend and amend the statutory authority for the controls, the Economic Stabilization Act of $1970 .{ }^{1}$ The amendments to the Act, approved by Congress and signed by the President on December 22, elaborate the standards to which control regulations and decisions must conform and create a specialized system for judicial review of stabilization measures. ${ }^{2}$ In addition, the amendments direct the control agencies to establish by regulation appropriate procedures, including agency review, "available to any person for the purpose of seeking an interpretation, modification, or rescission of, or seeking an exception or exemption from ... rules, regulations, and orders."3 On January 21, the Cost of Living Council, the Pay Board, the Price Commission, and the Internal Revenue Service, pursuant to this statu-

184 Stat. 799 (1970), as amended, 84 Stat. 1468 (1970), 85 Stat. 13 (1971), 85 Stat. 38 (1971). The Act authorized the President to "issue such orders as he may deem appropriate to stabilize prices, rents, wages, and salaries at levels not less than those prevailing on May 25, 1970" and to make "such adjustments as may be necessary to prevent gross inequities." 84 Stat. 799 (1970). This authority was, under the original Act, to expire on February 28, 1971, but was extended by Pub. L. 92-15, $\$ 3$ (May 18, 1971) to April 30, 1972. 85 Stat. 38 (1971). On August 15, 1971, invoking this statutory authority, the President imposed a ninety-day freeze on prices, rents, wages, and salaries in order to place an immediate brake on the rate of inflation and to provide an interim period in which to devise more flexible mechanisms for securing economic stability. Exec. Order No. 11615, 36 Fed. Reg. 15727 (1971), as amended, Exec. Order No. 11617, 36 Fed. Reg. 17813 (1971). On October 15, the general structure of the postfreeze control program, Phase II, was established. The Pay Board and the Price Commission were created to prescribe regulations and standards and to make rulings and decisions governing wage and price increases in accordance with general policies formulated by the Cost of Living Council. Exec. Order No. 11627, 36 Fed. Reg. 20139 (1971), as amended, Exec. Order No. 11630, 36 Fed. Reg. 21023 (1971). The Internal Revenue Service was subsequently delegated responsibility to administer the service and compliance functions under the controls. Cost of Living Council Order No. 5, 36 Fed. Reg. 21798 (1971). The ninety-day freeze was terminated on November 13 , and the control program formulated by the Phase II agencies went into effect. For the full text of a White House background paper describing the structure and purposes of the postfreeze stabilization program, see U.S. CoDE CoNG. \& AD. NEws, No. 8, at 2226 (1971) [hereinafter cited as White House Background Paper].

2 Economic Stabilization Act Amendments of 1971, 85 Stat. 743 (1971) [hereinafter cited as 1971 Amendments].

31971 Amendments § 207(b). 
tory command, issued comprehensive regulations to govern the procedural structure of the control system. ${ }^{4}$

Both Congress, in its amendments to the Act, and the control agencies, in their regulations, may have been responding, ${ }^{5}$ in part at least, to the decision of the District Court for the District of Columbia in Amalgamated Meat Cutters $v$. Connally, ${ }^{6}$ in which a three-judge panel held that the Act was not, on its face, an unconstitutional delegation of legislative power to the President. The plaintiff union contended that the Act, lacking any indication whatever of the standards and procedures by which the stabilization program was to operate, gave the President a " 'blank check' for internal affairs which is intolerable in our constitutional system."7 The court responded that the Act could not be given the "extremist" interpretation proposed by the union because, first, the Act implied a duty to take whatever action necessary to insure general fairness and broad equity in light of what is feasible in a general control program; 8 second, control activities would be limited by administrative standards developed as the program progressed, against which particular actions could be tested; 9 third, there was a presumption of judicial review of stabilization measures; $;^{10}$ and, finally, the stabilization agencies would be subject to the provisions of the Administrative Procedure Act. ${ }^{11}$ While the court declined to declare the Act an unconstitutional delegation, it placed the federal government on notice that in the course of administering the Act, there must be established procedural safeguards and standards appropriate to the nature and activities of the program and commensurate with the interests that it affects. ${ }^{12}$ This comment will examine the procedural regulations promulgated by the control agencies, as well as the administrative and judicial review provisions of the 1971 amendments, in light of the requirements of due process. The central inquiry of this study will be whether, because of the wide-

4 Cost of Living Council Procedural Regulations, 6 C.F.R. $\S \S 105$ et seq. (1972); Pay Board Procedural Regulations, 6 C.F.R. $\$ \S 205$ et seq. (1972); Price Commission Procedural Regulations, 6 G.F.R. $\S 305$ et seq. (1972); Internal Revenue Service Procedural Rules Relating to Economic Stabilization, 6 C.F.R. $\$ \S 401$ et seq. (1972).

5 See S. REP. No. 92-507, 92d Cong., 1st Sess. 2 (1971).

6337 F. Supp. 787 (D.D.C. 1971) (Leventhal, J.).

7 Id. at 754 .

$8 I d$. at $755-58$.

o Id. at 758-59.

$10 \mathrm{Id}$. at $759-61$.

11 Id. at $761-62$.

12 Amalgamated Meat Cutters is an example of an incipient trend in the case law toward viewing the problems against which the otherwise effectively moribund nondelegation doctrine is directed as questions of due process and administrative fairness rather than simply of separation of powers. See K.C. Davis, Administrative LAw Texr $\S 2.09$ ( $8 \mathrm{~d}$ ed. 1972). 
scale application of the present controls and because of the felt need for speed, uniformity, and efficiency in their operation, there is fundamental tension between comprehensive economic controls, on the one hand, and normal standards of procedural fairness, on the other.

\section{The Relationship Between the Procedural and Substantive Charagteristics of the Controls}

The experience of the federal government during both World War II and the Korean conflict with direct control of wages and prices figured prominently in congressional consideration of both the original Act and the 1971 amendments. ${ }^{13}$ The amendments that the Administration first proposed were in some respects modeled after the statutory provisions that governed the wartime control authorities. ${ }^{14}$ The Administration apparently contemplated foreshortened administrative and judicial review procedures similar in some ways to those employed in the prior control periods ${ }^{15}$ - procedures that had been upheld by the Supreme Court against arguments that they violated procedural due process. ${ }^{16}$

It is questionable, however, that the administrative and judicial review provisions of the wartime control programs can provide models against which the adequacy of the provisions of the present program can be measured or that the decisions holding the wartime provisions constitutional indicate that similarly summary procedures can constitutionally be employed in the present system of comprehensive controls. In the Amalgamated Meat Cutters decision, the court stated that the "context of the 1970 stabilization statute includes the stabilization statutes passed in 1942, and the stabilization provisions in Title IV of the Defense Production Act of 1950, and the 'common lore' of antiinflationary controls established by the agency approaches and court

13 Concerning the original Act, see H.R. REP. No. 9I-1330, 91st Cong., 2d Sess. (1970); Hearings on H.R. 17880 Before the House Comm. on Banking and Currency, 91st Cong., 2d Sess. (1970); 116 CoNG. REc. 26795-843 (1971) (House debate). Concerning the 1971 amendments, see, for example, 117 Cong. REc. S19940-95 (daily ed. Dec. 1, 1971) (particularly Remarks of Senator Proxmire).

14 The Administration's amendments were submitted to Congress on October 19, 1971 and introduced as companion bills. S. 2712, H.R. 11309, 92d Cong., 1st Sess. (1971).

15 See text and notes at notes 60-61, 90 infra. The White House Fact Sheet on the 1971 amendments noted, for example, that section 207 of the Senate bill would provide that "any agency administering the Stabilization Program will be exempt from the Administrative Procedure Act (APA), except for the public information section. The ordinary procedure of the APA would involve delay and a great deal of manpower. Phase II agencies will be allowed to develop streamlined procedures." CCH Economic Controls, No. 27, at 3 (Oct. 21, 1971).

16 Text and notes at notes $30-34$ infra. 
decisions."17 While this context may help indicate, in a rough way at least, some of the legal and constitutional parameters within which detailed, universal regulation of prices and wages must operate, the degree to which prior experience with controls can provide guidance in resolving the legal questions that may arise under the present controls is limited by the differences between the substantive policies of past control schemes and those of the program now in operation. ${ }^{18}$

The present control program, like the wartime control programs before it, is intended to mitigate the dangers that inflation presents to the economy and society. ${ }^{19}$ But those responsible for initiating and administering the present controls perceive the economic problems that have caused the current inflation as essentially different from those problems with which the wartime control agencies had to deal. Whatever the correctness of these differing perceptions of inflation, they have led to differences between the substantive characteristics and procedural requirements of the present stabilization scheme and those of the World War II and Korean conflict programs.

\section{A. Characteristics of the Wartime Controls}

The prevalent diagnosis of the causes of the intensely inflationary periods that attended American entry into both World War II and the Korean conflict is premised on the demand-pull theory of inflation -that a general increase in price levels is caused by an increase in aggregate demand for goods and services. ${ }^{20}$ Thus, the inflationary pressures attending outbreaks of war are the product of sharp increases in governmental expenditures for materiel and the resulting economic

17337 F. Supp. at 748.

18 The court in Amalgamated Meat Cutters recognized that "[t]he approaches and decisions under the earlier laws are certainly not 'frozen' as guidelines for the present law .... . The fact that there are significant differences between the inflationary policies of 1970 and the inflationary problems of 1942 and 1950 provides additional reasons for differences in policies." 337 F. Supp. at 748-49. Since it found that the APA was, under the terms of the Economic Stabilization Act of 1970, applicable to the control agencies, the court concluded that "it is hollow to say that the 1970 Act was void $a b$ initio for failure to make provision for these matters. We have no basis or warrant for considering-or rather speculating-in this action whether the ongoing administration of the stabilization program may become subject to challenge for failure to provide reasonable and meaningful opportunity for interested persons to present objections or inequities that undercut the premise of broad equity, or for officials to take these into account, or for courts to discharge their function of judicial review." Id. at 762. The court thus implied the kind of functional relationship between the content of the control program and the administrative procedures appropriate to it that this comment explores.

19 See Radio and Television Address by President Nixon, Aug. 15, 1971, in U.S. Cone Conc. \& AD. NEws, No. 7, at 1933 (1971).

20 R. LIPSEY \& P. STEINER, EcoNomics 764 (2d ed. 1966). 
dislocation. ${ }^{21}$ Although these effects can be offset somewhat by fiscal and monetary measures, it has been argued that the time necessary for these measures to become effective cannot be afforded; inflationary pressure is so intense that it must be suppressed as quickly and thoroughly as possible, not only to avoid social and economic disruption, but also to insure that by the manipulation of wage and price levels to shift resources to the defense sector of the economy, mobilization will proceed efficiently. ${ }^{22}$

In order to meet these problems, the wartime control programs attempted to establish a system of planned allocation by controlling the normal market mechanisms for allocating resources, the forces of supply and demand. ${ }^{23}$ This was accomplished, after brief attempts to limit controls to particularly crucial sectors, by across-the-board price freezes followed by regulations prescribing ceiling prices for specific commodities and products. ${ }^{24}$ Price controls were based on the principle of costabsorption-that individual firms could not sell products at prices above those prescribed by regulation even if a firm's cost increase had made sales at the ceiling price unprofitable. ${ }^{25}$ The essential concern was

21 The shifting of resources to the defense sector causes increasing scarcity of consumer goods while, because of the full employment of manpower occasioned by war production, the demand for consumer goods is increasing as well. Comment, Legal and Economic Aspects of Wartime Price Control, 51 YALE L.J. 819, 820-21 (1942). The severe inflation attending the outbreak of the Korean conflict probably had a strong psychological component -demand increased dramatically because of fear of impending shortages and higher prices, while wages and prices were raised in anticipation of the imposition of controls. Ross, Guideline Polioy-Where We Are and How We Got There, in GUIDELINEs, INFormat. CONTROLS, AND THE MARKETPLACE 97, 118-19 (G. Shultz \& R. Aliber eds. 1966).

22 See Defense, Controls, and Inflation, 216-22 (A. Director ed. 1952) (remarks of Charles Hitch); Taylor, Wage Stabilization in a Defense Economy, 100 U. PA. L. REv. 499, 500-01 (1952).

23 During World War II, the statutory authorities for the wartime controls were the Emergency Price Control Act, 56 Stat. 23 (1942), as amended, Stabilization Act, 56 Stat. 765 (1942); the Stabilization Extension Act, 58 Stat. 632 (1944); and the Price Control Extension Act, 60 Stat. 664 (1946). During the Korean conflict, they were the Defense Production Act of 1950 tit. IV, 64 Stat. 803, as amended, 50 U.S.C. App. \$\$ 2101 et seq. (1954).

24 For a brief history of the evolution of the World War II price control policies, see H. MANSFIELd ET AL., A SHORT HistoRY OF OPA 39-81 (OPA Historical Reports on War Administration, Gen. Pub. No. 15, 1947). For a description of the price control structure established during the Korean conflict, see Letzler, The General Ceiling Price Regulation -Problems of Coverage and Exclusion, 19 LAw \& ConTEMP. Prob. 486 (1954).

25 The general principle of cost absorption was modified in two ways, by the industryearning standard and the product-cost standard. If either or both of these standards indicated that a particular price ceiling was, for the industry as a whole, too low to insure continued production, the price ceiling could be raised. See Gruber, Establishment and Maintenance of Price Regulations-A Study in Administration of a Statute, 96 U. PA. L. Rxv. 503-08 (1948). For a comprehensive description of OPA pricing standards, see D. Gavers, R. Dickerson, et al., Problems in Price Control: Pricing Standards (OPA Historical Reports on War Administration, Gen. Pub. No. 7, 1947). During the Korean period, 
thus predominantly with the general economic situation of defined product and industry sectors rather than with the particular cost and profit circumstances of individual firms. ${ }^{26}$

\section{B. The Judicial Response to Wartime Control Procedures}

The major task of the wartime control agencies was to define industry and product sectors and employee categories and then to set price and compensation ceilings to insure continued production and stable employment patterns. Challenges to the validity of price and rent control regulations were allowed only on the ground that the prescribed ceilings were too low to allow minimally profitable production for the industry as a whole or that the product and industry sectors had been too broadly defined. ${ }^{27}$ The challenges could be instituted in only one way -by filing a protest with the control agency..$^{28}$ If the protest was denied, a complaint could be filed with the Emergency Court of Appeals, which, during both the World War II and Korean periods, had exclusive jurisdiction to review price and rent stabilization matters. No other court could restrain or enjoin enforcement of control regulations, and the Emergency Court could grant injunctive relief only after a final judgment; no preliminary injunctive relief was available. ${ }^{29}$

The constitutionality of the procedural framework in which the World War II control system operated was challenged in two cases that came before the Supreme Court in 1944. In Bowles $v$. Willingham, ${ }^{30}$ the Court held that due process did not require notice and a hearing either before the Price Administrator fixed generally applicable maximum rents for housing in defense rental areas or before the Administrator

the industry-earning and product-cost standards were used to adjust freeze period prices; relatively few commodity price ceilings were established. Nonetheless, cost absorption was the basic principle of control. Nelson, OPS Price Control Standards, 19 LAW \& CoNTEMP. PROB. 554, 565-77 (1954).

26 As a general matter, wage controls during the wars were, like price ceilings, keyed to general economic criteria varying by sector and firm. See BNA 1971 LAB. REL. REP., WAGE \& SALARY Controls 511-15.

27 See N. Nathanson, Problems in Price Control: Legal Phases pt. 1, 5-15 (OPA Historical Reports on War Administration, Gen. Pub. No. 11, 1947).

28 Hyman \& Nathanson, Judicial Review of Price Control: The Battle of the Meat Regulations, 42 IrL. L. REv. 584, 587 (1947). For a full description of the Korean conflict control agency procedures, see Reports on Control Agencies by the Committee on Emergency Control Agencies, Administrative Law Section, Bar Association of the District of Columbia, 20 GEO. WASH. L. REv. 559 (1952).

29 Hyman \& Nathanson, supra note 28, at 587-88. The provisions for judicial review of price regulations during World War II and the Korean conflict were, in most respects, identical. Compare Emergency Price Control Act \$§ 203-04, 56 Stat. 23 (1942), with Defense Production Act $\$ \S 407-08,64$ Stat. 803 (1950). No statutory provision was made for judicial review of wage regulations. See Field, Economic Stabilization under the Defense Production Act of 1950, 64 HARv. L. REV. 1, 20-21 (1950).

30321 U.S. 503 (1944). 
determined the appropriate housing category into which the property of a particular landlord fell (and thus the applicable rental ceiling). In Yakus v. United States, ${ }^{31}$ the Court held that the foreshortened, limited, and exclusive judicial review procedures, as well as the limitations on available relief prescribed by the Emergency Price Control Act of 1942, ${ }^{32}$ were consistent with the requirements of due process. ${ }^{33}$ The Court also denied due process challenges to the particulars of the protest procedure, holding that the "authorized procedure is not incapable of affording protection to petitioners' rights required by due process." 34

One commentator has suggested that these decisions may have rested on the fact that the wartime controls were exercises of the war power and that the requirements of due process applicable to wartime emergency measures may well differ from those appropriate for controls instituted under the commerce power during times of relative peace. ${ }^{35}$ There are, indeed, indications in the opinions that the Court was concerned primarily with the emergency nature of the controls and their indispensable function as part of the war effort. A more adequate analysis of these decisions, however, might be directed not to the formal powers under which the controls were undertaken, but rather to the problems that the controls were designed to meet and the substantive nature of the programs. ${ }^{36}$ As the discussion above indicated, the wartime controls were designed to counter the inflationary pressures caused by severe disequilibria in demand and to allow mobilization to proceed as rapidly and efficiently as possible. In order to insure that the method

31321 U.S. 414 (1944).

32 Emergency Price Control Act §§ 203-04, 56 Stat. 23 (1942).

33 Yakus was an appeal from a criminal conviction for violation of a maximum price regulation. The principal grounds of contention, in addition to the allegation that the Emergency Price Control Act was an unconstitutional delegation of legislative power, were that (1) the prohibition against challenging the legality of the regulation as a defense in the criminal trial and (2) the limits on appeals to the Emergency Court and on available relief constituted denials of due process, 321 U.S. at 437-48; see Hyman \& Nathanson, supra note 28 , at $588-93$.

34321 U.S. at 435. The petitioners in Yakus had made no attempt to avail themselves of the protest procedure. Because of this failure to exhaust administrative remedies, the Court said: "Only if we could say in advance of resort to the statutory procedure that it is incapable of affording due process to the petitioners could we conclude that they have shown any legal excuse for their failure to resort to it or that their constitutional rights have been or will be infringed." 321 U.S. at 435.

35 Kurland, Guidelines and the Constitution: Some Random Observations on Presidential Power to Control Prices and Wages, in Guidelines, Informal ConTrols, aNd The MarKETPLACE, supra note 21, at 209, 221.

36 The Court in both Yakus and Willingham cited numerous peacetime precedents in support of its holdings that the details of the administrative and review procedures complied with due process standards. 321 U.S. at 431-48; 321 U.S. at 519-21. On this point, see the dissent of Justice Roberts in Yakus. 321 U.S. at 459-60. 
of resource allocation established by the control system could operate, the ceiling price regulations had to be imposed uniformly and concurrently on all of the firms in an industry. This could be accomplished only by administrative and judicial review procedures that were summary in nature.

In upholding these measures, the Court in the Yakus and Willingham cases applied, in effect, what has come to be a standard principle of due process adjudication-that the requirements of due process are at once a function of the kinds of problems that the government must meet, the kinds of actions that it undertakes, and the nature of the private interests that these actions affect. The requirements depend, in short, on a balancing of the public and private interest in procedural fairness against the costs that certain procedures may entail. ${ }^{37}$ Thus, in Yakus, the Court noted: "Inflation is accelerated and its consequences aggravated by price disparities not based on geographic or other relevant differentials. The harm resulting from delayed or unequal price control is beyond repair." The Court looked to the harm that would result if enforcement of the price ceilings "were delayed or sporadic or were unequal or conflicting in different parts of the country" as justification for the unitary and foreshortened review procedure and the ban on preliminary relief. ${ }^{38}$ Similarly, in Willingham, the Court said:

Congress was dealing here with the exigencies of wartime conditions and the insistent demands of inflation control .... It chose a method designed to meet the needs for rent control as they might arise and to accord some leeway for adjustment within the formula which it prescribed. At the same time, the procedure which Congress adopted was selected with the view of eliminating the necessity for "lengthy and costly trials with concomitant dissipation of the time and energies of all concerned in litigation rather than in the common war effort."

The Court concluded that "to require hearings for thousands of landlords before any rent control order could be made effective might have defeated the program of price control" and that where Congress has

37 See, e.g., Hannah v. Larche, 363 U.S. 420,442 (1960), and the Court's elaborate appendix comparing the administrative procedures of a number of federal agencies, including the OPS and the OPA, $i d$. at 454-85. For a statement of the principle contemporary with Yakus and Willingham, see NBC v. FCC, 132 F.2d 545, 560 (D.C. Cir. 1942), in which the court said that minimum compliance with procedural due process "will vary to a considerable extent with the nature of the substantive right, the character and complexity of the issues, the kinds of evidence and factual material, the particular body or official, and the administrative functions involved ...." Gf. Newman, The Process of Prescribing Due Process, 49 CALIF. L. REV. 215 (1961).

38321 U.S. at 432. 
provided for judicial review after the regulations are made effective, "it has done all that due process under the war emergency requires." 39

To accomplish the purposes of the wartime control programs, it may have been necessary to employ relatively summary administrative and judicial review procedures, and in measuring the adequacy of these procedures, the Court looked to the emergency nature of the controls and the manner in which they were applied. ${ }^{40}$ It would, therefore, be a mistake to extrapolate from these decisions any notion that the present control program either can or should operate only by means of summary procedural methods. Instead, normal principles of due process adjudication must be used to weigh the benefits and costs of the procedures established by the present controls; and these can be determined only by examining the purposes of the program and the manner in which it is intended to operate.

\section{Characteristics of the Present Controls}

While the wartime inflation periods were characterized by extreme, if temporary, disequilibria in demand, the present inflation period has been characterized, at least in recent years, by fairly stable demand. A variety of explanations has been offered as to how inflation, on the one hand, and stable demand, relatively substantial unemployment, and unused industrial capacity, on the other-once thought incompatible phenomena-have somehow managed to coexist. ${ }^{41}$ One of these explanations, the cost-push theory, identifies the market power of large labor unions and oligopolistic industries as a major contributor to the problem -the unions demand increases in wages even when there is no excess demand for labor, and employers accede to these demands because they are able, due to their market power, to pass the increased costs on to the consumer. ${ }^{42}$ Another explanation regards such inflation as a psychological phenomenon-higher wage demands and price increases are generated by the expectation that inflation in the immediate future will continue or increase in rate as it has in the past; thus, the experience of inflation generates inflation. ${ }^{43}$ Whatever the causes of the present

39321 U.S. at 520-21; cf. Schwartz, Procedural Due Process in Federal Administrative Law, 25 N.Y.U.L. REv. 552, 563-66 (1950).

40 The Emergency Court employed principles similar to those in Yakus and Willingham to deny due process challenges to the administrative and review provisions of the World War II controls. See, e.g., Avant v. Bowles, 139 F.2d 702, 706 (Emer. Ct. App. 1943); Taylor v. Brown, 137 F.2d 654, 660-63 (Emer. Ct. App.), cert. denied, 320 U.S. 787 (1943).

41 Solow, The Case Against the Case Against the Guideposts, in GuIDEIINEs, INFormat CONTROLS, AND THE MARKETPLACE, supra note 21, at 41-42.

42 See Ackley, The Contribution of Guidelines, in Guidelines, Informal ConTrols, and THE MARKETPLACE, supra note 21, at 67, 68-72; Ross, supra note 21, at 101-02.

43 For an explanation of how price expectations can affect demand, see R. LIPSEY \& $P$. 
inflation, ${ }^{44}$ the intent of the present control program is not to place limits on demand, but rather to reduce the rate of inflation by limiting the effects of factors other than supply and demand-whether these are identified as market power or expectation or both-on individual wage and price decisions that help generate inflation.

Consistent with this analysis, the present controls, unlike the wartime controls, are not directed to defining maximum wage and price levels by product and industry sectors. They are concerned instead with placing some limits on the discretion of individual firms to raise the wages that they pay their employees and the prices at which they sell their products-limits in addition to, rather than in place of, those imposed by the market. The price control regulations promulgated by the Price Commission, for example, are generally premised, not on the costabsorption principle of the wartime controls, but rather on flow-through of costs. Firms are allowed to increase prices over freeze period levels by amounts corresponding to increases in allowable costs (i.e., all costs, direct or indirect, except those specifically disallowed by the Commission $^{45}$ ), but only if such increases will result in pretax profit margins, calculated as a percentage of sales, no greater than those that prevailed during a defined base period. ${ }^{46}$ Thus, application of the price control regulations necessarily varies from firm to firm because any allowable

STEINER, supra note 20 , at 554 . Households may be willing to pay a premium for goods purchased now so long as it is less than the anticipated price increase; by the same token, unions, in negotiating long-term contracts may take into account the expected rate of in. flation during the course of the contract, in order to calculate contract demands that will result in a real wage increase. These effects may help to produce a "market rate of inflation." There are indications that the Administration accepts the notion of inflation as a psychological phenomenon as a working premise for the Phase II controls. See White House Background Paper, supra note 1, at 2226. The House Report on the Economic Stabilization Act of 1970 spoke of the many witnesses before the Committee who had "called on the Congress to provide discretionary standby authority to the President to impose ... controls to combat and break the back of inflation and the inflationary psychology which pervades our thinking and our economy." H.R. REP. No. 91-1330, supra note 13, at 9.

44 Fiscal and monetary policies might, if severe enough, eventually be able to reduce the present inflation rate significantly, but not without causing debilitating and politically inexpedient subsidiary effects, such as increased unemployment and further slackening in economic growth. See Solow, supra note 41, at 42-44. Controls are therefore invoked in order to slow the wage-price spiral, and, at the same time, fiscal and monetary policies are used to further employment and growth by increasing aggregate demand.

46 Price Commission Regulations, 6 C.F.R. $\$ 800.5$ (1972).

46 This rule applies to manufacturers. Id. \$ 300.12. Similarly, retail and wholesale firms must calculate prices on the basis of their customary initial percentage mark-ups, which may be no higher than those that the firm employed during the base period; again, a firm may not increase its prices beyond an amount that would bring its net profit, calculated as a percentage of sales, to a level greater than that of the base period. $I d$. $\S 300.13$. For the rules as to service firms, see $i d$. $\$ 300.14$. 
price increase depends on the peculiar cost and profit circumstances of the individual firm. The same features pervade the wage control regulations promulgated by the Pay Board.47

\section{The Procedural Consequences of the Substantive Controls}

There are three central differences between the control programs instituted during World War II and the Korean conflict and the program now operating. First, the wartime controls were temporary, emergency measures, to be lifted when the emergency ended; the present controls, because they are a response to an economic emergency caused by problems endemic in the economic structure, are open-ended in duration and may, in some form, be permanent or at least recurrent. Second, the wartime controls were intended to be relatively rigid and were designed to further the war effort as much as to spare the nation the vicissitudes of inflation. The present controls are designed to preserve a degree of fluidity in the wage and price structure within individualized limits. Thus, the wartime controls established specific wage and price ceilings applicable universally to industrial and product sectors. The present controls, in contrast, are keyed directly to the operations and circumstances of individual firms. However detailed the control regulations are made, their precise application will remain, to some degree, a matter of judgment and interpretation-functions that the procedural structure of the controls must be designed to provide.

Perhaps the most important distinction between the wartime and present controls, however, concerns the degree to which they were intended to interfere with the normal resource allocation function of the market economy. The central tenet of price theory is that changes in price in a free economy directly reflect the workings of the market mechanism-the dynamic changes in the relative levels of supply and demand that, in turn, are the result of millions of independent decisions by producers and consumers. This market mechanism, operating in the context of a competitive enterprise system, theoretically allocates resources with maximum efficiency. ${ }^{48}$ The wartime control agencies, because of the severe disequilibria in demand caused by the war effort, were compelled

47 The wage control regulations allow a maximum aggregate wage and salary increase of 5.5 percent annually over the rate paid at the end of the freeze period or before the effective date of a new wage agreement. The standard does not apply to each individual employee but to the average increase in an "appropriate employee unit," defined as all employees in a bargaining unit or in a recognized employee category. The wage controls, like the price controls, are thus keyed to circumstances-pay practices and employee classification systems-that vary widely from firm to firm. Pay Board Regulations, 6 C.F.R. §§ 201.10-.16 (1972).

48 See G. Stigler, The Theory of Price 14-16 (3d ed. 1966). 
to control supply and demand, and thus to manipulate the allocation of resources, by imposing absolute categorical ceilings on wage and price levels. The present control program, in contrast, has no resource allocation function at all; it is intended to reduce the influence only of those forces other than supply and demand that affect individual wage and price decisions and thus contribute to the rate of inflation.

These considerations bear directly on the appropriateness of various procedural safeguards in the context of the present control program. In measuring the adequacy of the procedural mechanisms by which the World War II control system operated, the Supreme Court in the Yakus and Willingham cases took into account the necessity of relatively summary procedures if the control program was to be effective and "the dangers to price control as a preventive of inflation if the validity and effectiveness of prescribed maximum prices were to be subjected to the exigencies and delays of litigation ...." ${ }^{49}$

Under the present system, however, such summary procedures would not only be unnecessary; they would be dysfunctional to the purposes of the controls as well. In the 1971 amendments, Congress recognized the necessity that the control program interfere as little as possible with the market mechanism; it required the control agencies to make "such general exceptions and variations as are necessary to foster orderly economic growth and to prevent gross inequities, hardships, serious market disruptions, domestic shortages of raw materials, localized shortages of labor, and windfall profits." 50 This requirement of exceptions is essential if the control program is to meet the pressures placed on its constraints by the operation of market forces. The individualized ceilings imposed by the control regulations inevitably limit the degree to which firms are able to respond to changes in supply and demand and may, therefore, come to interfere with the fundamental workings of the market. In short, market forces are likely, in the long run and in some sectors, to press sharply against the constraints of the controls unless exceptions, wherever appropriate, are made.

In addition, because the precise restrictions of the controls vary with the price, profit, and wage structure of each firm, there will undoubtedly be disputes as to the correct application of the regulations to individual circumstances. It is essential, therefore, that parties affected by the controls have some means to present their situations to control authorities so that they can, if nothing else, find out precisely what the controls allow or forbid them to do. For the control agencies to perform these

49 Yakus v. United States, 321 U.S. 414, 432 (1944).

c0 1971 Amendments § 203(b)(2). 
two basically adjudicative functions ${ }^{51}$-to make informed decisions as to the necessity and extent of exceptions and the correct application of the control regulations to particular facts-the parties subject to the controls must be allowed to present fully to the control authorities the facts and arguments relevant to their case.

The procedures appropriate to such determinations involve costs, particularly because of the potentially enormous number of grievances and challenges with which control authorities may have to deal. But these costs are greatly exceeded by the benefits of adequate administrative and judicial review machinery. First, unless appropriate procedures are devised to deal with petitions for exceptions, it is at least less likely that exceptions will be granted, however necessary or desirable they may be to avoid market disallocation. Second, unless adequate administrative precedures are available, firms not subject to the prior approval and periodic reporting requirements ${ }^{52}$ may prefer to respond in their normal fashion to the pressures of the market rather than to undertake voluntarily the rigors of compliance. ${ }^{53}$ There is, in fact, some evidence that this phenomenon is already occurring. ${ }^{54}$ Administrative procedures are likely to be significantly less costly than primary reliance on policing efforts and enforcement by the courts through criminal penalties or injunctive relief. Enforcement of the controls will be more difficult than it was in the World War II and Korean conflict periods because, unlike the clear, objective standards of the sector price ceilings, the precise limitations on wage and price increases depend on a multiplicity of

61 For a description of the functions of adjudicative proceedings and a collection of cases concerning the procedures appropriate to them, see K.C. DAVIS, ADMinistrative LAW Texr ch. 8 (3d ed. 1972).

62 Under the Phase II regulations, all business units are divided into three groups. The divisions as to prices are based on annual volume of sales-firms with annual sales of $\$ 100$ million or more are required to notify and obtain the prior approval of the Price Commission before raising prices on any product; firms with annual sales of $\$ 50$ million or more are required to report periodically to the Commission any changes in prices, costs, and profits; other firms, while not required to obtain prior approval or to report on a regular basis, are nonetheless subject to the price regulations. The wage controls operate through a similar three-tiered classification system based on the number of employees whom proposed pay increases will affect. Cost of Living Council Regulations, 6 C.F.R. $\S \S 101.11-.15,101.21-.25$ (1972).

53 Cf. Friedman, What Price Guideposts?, in Gumelines, INFormal ConTrols, AND THE MARKETPLACE, supra note 21 , at 17, 37-38.

54 See Wall Street Journal, Feb. 7, 1972, at 16, col. 1 (Midwest ed.):

Lumber and plywood prices are bumping against their authorized ceilings and have even broken through in some cases, as a result of what lumbermen call an "unusually strong" market for this time of year. Despite the price lids, ... lumbermen say continued buying pressure is bound to force prices higher.... Compounding the problem is confusion over which price boosts are permissible, and which aren't.... Some market sources say continued confusion over ceiling policies can only add to what is already considerable upward pressure on demand. 
factors peculiar to each firm. ${ }^{55}$ In addition, adequate preenforcement procedures may result in more widespread compliance with control standards. Even with far more enforcement personnel than the Administration has thus far provided, ${ }^{56}$ inspections and, thus, court actions against violators would be largely hit-or-miss, and firms might calculate - particularly when pressed by the supply and demand forces of the market-that the benefits of noncompliance would outweigh the likelihood and consequences of apprehension.

An adequate procedural system will also perform another function crucial to the success of the controls. Administrative and judicial review procedures can provide the agencies with a continuous flow of information about the operation of the regulations in specific factual contexts and thus serve as a valuable adjunct to the rule-making process. Taken together, these benefits of procedures appropriate to the kinds of determinations that the control agencies must make not only exceed the costs that they may entail; they also provide the means by which, and perhaps by which alone, the purposes of the controls can be achieved.

\section{Procedural Structure of the Controls}

The considerations outlined above indicate that if the present scheme of economic control is to work effectively, it must operate by means of procedural mechanisms that maximize participation by affected parties in order to insure that the restrictions imposed by the control regulations will be adjusted to the exigencies of individual circumstances. The following sections of this comment measure the extent to which the administrative and judicial review provisions of the 1971 amendments and the procedural regulations promulgated by the control agencies succeed in meeting this need.

\section{A. Administrative Procedures}

Having concluded that the requirements of the Administrative Procedure $\mathrm{Act}^{57}$ would result in "too cumbersome and dilatory a procedure," 58 Congress exempted, in the 1971 amendments, the control

55 Because of this, section 210 of the 1971 amendments, which allows private damage actions for prices charged in excess of those allowed under the control regulations, appears to be a rather ineffective appendage. Such private actions were allowed under the World War II and Korean conflict stabilization statutes, but violations of the wartime price ceilings were relatively easy to detect. Detection of violations of the current regulations, in contrast, requires detailed knowledge of a firm's past and present costs, profits, and customary mark-ups and is, therefore, almost impossible for private individuals-the consumers. Thus, government inspection and enforcement is more important.

56 See Wall Street Journal, Mar. 14, 1972, at 16, col. I (Midwest ed.).

575 U.S.C. $\$ \S 551$ et seq. (1970).

58 S. REP. No. 92-507, supra note 5, at 8. 
agencies from most of the Act's provisions. ${ }^{59}$ It rejected, however, the Administration's proposal ${ }^{60}$ that the agencies, like those of the Korean period, ${ }^{61}$ be exempted from all of the Act's requirements. ${ }^{62}$

1. Rule Making. The 1971 amendments subject the control agencies to the section of the APA that governs the rule-making process, the procedures by which generally applicable regulations are formulated. ${ }^{.3}$ The section, when it applies, requires that notice of proposed rule making be published in the Federal Register; interested parties are then given "an opportunity to participate in the rule making through submission of written data, views, or arguments with or without opportunity for oral presentation." 64 The control agencies have to date, however, almost universally taken advantage of the provision in the section that allows agencies to disregard the prescribed rule-making procedure "when the agency for good cause finds . . . that notice and public procedure thereon are impracticable, unnecessary, or contrary to the public interest." outset of the Phase II controls were designed to govern nearly all sectors of the economy. Because of the extremely broad scope of these initial regulations and the time pressures under which they were formulated, ${ }^{66}$ the APA's rule-making procedures would have been of little utility. But in recent months, the rule-making activities of the control agencies have become more particularized; their attention has been directed increasingly to the formulation and modification of rules to meet problems of more localized significance pertaining only to certain kinds and categories of firms. ${ }^{67}$ Under these circumstances, the rule-making procedure of the APA could serve as an instrument to secure the views

591971 Amendments § 207(a).

60 S. 2712, 92d Cong., 1st Sess. $\$ 207$ (1971). The Administration's proposal would, however, have subjected the agencies to the Freedom of Information Act, a part of the APA. 5 U.S.C. $\$ 552(1970)$.

61 Defense Production Act of 1950, 50 U.S.C. App. $\$ 2159$ (1951). The Administrative Procedure Act was originally enacted in 1946 (60 Stat. 237) and did not apply to the World War II control agencies.

62 For the provisions of the APA to which the control agencies remain subject under the 1971 amendments, see text and notes at notes $63,70,87$ infra.

635 U.S.C. $\S 553(1970)$.

$64 I d$. $\$ 553(c)$. In most cases, substantive rules must be published at least thirty days before they are to take effect. $I d$. $\$ 553(\mathrm{~d})$.

$65 \mathrm{Id}$. § 553(b)(B).

60 The Phase II control agencies were established on October 15, and the initial, generally applicable regulations went into effect on November 13. See note 1 supra. These general regulations are those described in the text and notes at notes $45-47$ supra.

o7 See, for example, the Price Commission regulations governing institutional providers of health services, which were originally issued on December 30, 1971. 6 C.F.R. $\S 300.18$ (1972). 
and information available to those most immediately concerned and acquainted with the problems.

Since imposition of the initial, generally applicable wage and price regulations, the present control agencies have not been operating under time pressure comparable to that to which the wartime control agencies were subject. The wartime agencies were required to impose and adjust maximum price levels as quickly as possible in response to changes in supply and war needs in order to avoid misallocation of resources. ${ }^{68}$ The new regulations that the present agencies are now formulating involve adjustments in the methods of calculating permissible wage and price increases contained in the general regulations, tailoring them to the peculiar circumstances of certain kinds of firms. While the new regulations are being formulated, these firms will remain subject to the general regulations. Since the present controls are intended not to prevent any particular wage or price increase, but only to keep the rate of inflation for the economy as a whole within tolerable limits, the delay entailed in the APA's rule-making procedure would not impede the general effectiveness of the control program.

2. Adjudicative Proceedings. The administrative procedure section of the 1971 amendments requires the control agencies to "establish appropriate procedures, including hearings where deemed advisable," to consider requests for interpretations and modifications of, and exceptions to, control regulations, rules, and orders. ${ }^{69}$ The amendments exempt the agencies from all APA provisions relating to adjudicative proceedings, except for the requirement that prompt notice be given "of the denial in whole or in part of a written application, petition, or other request of an interested person made in connection with any agency proceeding," together with a brief statement of the grounds for the denial..$^{70}$ This requirement fills the need, often recognized by courts, for informing petitioners of the reasons and findings on which administrative decisions have been based; they provide interested parties with a basis for judging whether a challenge to the decision is appropriate and, at the same time, facilitate administrative and judicial review. ${ }^{\mathbf{1 1}}$

Under the provisions of the control agencies' procedural regulations, the possible requests for administrative determinations are divided into several categories: interpretations and rulings, exceptions, exemptions, reclassifications, and pay challenges. ${ }^{72}$ The procedures applicable to each

68 See text at notes $36-37$ supra.

681971 Amendments § 207(b).

705 U.S.C. $\$ 555(\mathrm{e})(1970)$.

71 See cases cited in K.C. Davis, Administrative LAW TEXT ch. 16 (3d ed. 1972).

72 Interpretations of the regulations as they apply to specific factual contexts are issued 
of these categories are in most respects similar. There are, however, some important differences, particularly as to the kinds of parties given standing to request an administrative decision.

The regulations allow any person to request an interpretation or ruling as to the application of the control regulations to particular circumstances. ${ }^{73}$ The procedural structure that has been established to deal with these requests advances in stages from the use of relatively informal devices (written applications and conferences) at the initial stages to more formal modes of procedure (including hearings) employed only when applicants feel sufficiently aggrieved by decisions made at earlier stages in the process to prosecute appeals to the agencies. Even then, a hearing is allowed only if the agency considers it necessary to adduce evidence in a case. ${ }^{74}$ An objection might be posed to this system that a hearing should be available at an earlier stage in the process in order to allow an applicant fully to present his case. In fact, however, most of the evidence and arguments relevant to the application of control regulations involve economic information and data that can be adequately presented in written form. In addition, interpretations and rulings will be made on the basis of information submitted by the applicant alone rather than information and arguments submitted by two or more opposing sides that could be clarified through oral presenta-

to applicants by the district offices of the Internal Revenue Service "only where a determination can be made on the basis of established rules as set forth in the regulations and guidelines of the Cost of Living Council, Pay Board, and Price Commission, or by rulings or court decisions." 6 C.F.R. § 401.2 (1972). Rulings are written statements interpreting and applying regulations and guidelines; they are issued by the Office of the Chief Counsel of the IRS. Id. § 401.2. The IRS has announced that in some circumstances, interpretations and rulings will not be available. $I d$. $\$ 401.205$ (1972). An exception is defined in the IRS regulations as "a waiver in a particular case of the requirements of any rule, regulation, or order," id. § 401.2; decisions as to exceptions are made by the appropriate control agency, id. § 401.304. An exemption is a general waiver from all control requirements. Id. § 4012. Reclassification from one price or pay category to another (see note 52 supra) can be made only by the Cost of Living Council. Id. \$§ 101.19, 101.29. Pay challenges are objections to any changes in wages or salaries made after November 13, 1971 in accordance with existing contracts or pay practices. $I d$. $\$ \S 205.2,201.14$.

73 Id. $\$ 401.202$.

74 A request for an interpretation or ruling can be initiated by submitting an application in writing to the district office of the IRS; the applicant may request an interview to discuss the application. Any person aggrieved by an adverse ruling or determination may file with the district director of the IRS an appeal, which will be decided by a district conferee after a conference with the appellant. If this appeal is denied, a further appeal may be filed with the appropriate control agency. If the appeal presents a prima facie case that the IRS determination was erroneous, the agency will determine whether additional evidence or a hearing is necessary before it makes its final decision. Id. $\$$ 401.101, 401.601-04 (IRS); cf. id. \$§ 105.20-.28 (Cost of Living Council), 205.20-.28 (Pay Board), 305.30-.38 (Price Commission). 
tions. ${ }^{75}$ Under these circumstances, the informal devices can be expected to dispose of the great majority of applications efficiently and fairly. Hearings can then be used as a corrective mechanism to determine whether decisions reached by means of less expensive and time-consuming procedures correctly applied the regulations to the facts. ${ }^{76}$ The procedures thus allow adequate participation by applicants to insure that proper interpretations and rulings will be achieved.

Requests for exemption from the controls or exceptions in the application of particular regulations may be initiated in the same manner as requests for interpretations, except that the applicant must present evidence sufficient to establish that "the application of economic stabilization regulations and guidelines will result in serious hardship or gross inequity." "77 Upon receiving the request, the control agency will decide whether an exception is appropriate; it will, however, reconsider its original decision if any person makes a prima facie showing that the decision was erroneous in fact or law. If a prima facie case has been made, the agency may direct that a hearing be held. The same procedure is used by the Cost of Living Council in considering reclassification requests. ${ }^{78}$ It is important to note that any party or group, not only the original applicant, that considers itself adversely affected by the grant or denial of an exception may resort to the reconsideration procedure. ${ }^{79}$ Contrary to the practice of the other agencies, the Pay Board regulations provide that the Board may, upon receipt of an application for an exception, invite the applicant and other interested parties to participate in formal or informal hearings before the initial decision on the application is made. ${ }^{80}$ This corresponds to the special procedure that the Board has devised to deal with pay challenges-upon receipt of the challenge, the Board notifies all interested parties that a challenge has been filed, and the parties may then request permission to participate in the proceedings. ${ }^{81}$

75 See id. \$ 401.101 .

76 For a description and evaluation of the closely analogous procedures that the IRS has employed in tax complaint cases since 1952, see P. Wolt, ADMinistrative LAW, ThE INFORMAL PROCESS 104-16 (1963).

776 C.F.R. \& 401.303(b)(1) (1972).

78 Id. $\$ \S 401.301-04$ (IRS), 105.30-.38 (Cost of Living Council), 205.30-.40 (Pay Board), 305.30-.38 (Price Commission).

79 See id. $\S \S 105.33$ (Cost of Living Council), 305.33 (Price Commission). Under the Pay Board regulations, only a "person aggrieved" (defined as "a person with a substantial pecuniary interest in a pay adjustment which is the subject of an adverse action," id. $\S 205.2)$ or another party to the initial proceedings may request reconsideration. Id. $\S 205.34$.

80 Id. \& 205.31(a).

81 The Pay Board will determine whether the parties requesting participation either 
In the processing of pay challenges, as well as of requests for exemptions and exceptions, hearings may be a necessary fact-finding device far more frequently than in the processing of requests for interpretations and rulings. It is essential to the success of the control program that exceptions be granted wherever necessary to effect the program's economic policies. The control agency's determination must, therefore, take into account all relevant factors in the applicant's circumstances. Consequently, it may be neither possible nor wise to measure the necessity of an exception or the validity of a pay challenge solely on the basis of information and arguments submitted by the applicant. This is particularly true in the case of Pay Board decisions because the interests of employees and employers may not often coincide and the proceedings can be, appropriately, adversary in nature.

It is difficult to ascertain solely from the regulations how frequently the control agencies contemplate that hearings will be necessary and, in particular, how liberal the Pay Board will be in authorizing participation in exception and pay challenge proceedings. The procedures outlined above can be effective administrative mechanisms for dealing with exception requests and pay challenges only if the agencies insure that all affected parties have a full opportunity to present the data and arguments that support their positions. The agencies should, therefore, allow hearings wherever a prima facie case has been made for an exception or pay challenge and should allow broad participation by all affected parties.

The 1971 amendments and the control agencies' procedural regulations seem to have established, on the whole, procedures appropriate to the functions and purposes of the control program. It is difficult to understand, however, why either the Administration or Congress thought it necessary to exempt the control agencies from the provisions of the APA governing adjudicative proceedings. ${ }^{82}$ Since the provisions apply only to those cases "required by statute to be determined on the record after opportunity for agency hearing," $\$ 3$ the agencies would have retained the same discretion in providing hearings that they do under the present amendments and regulations. The regulations, in fact, differ in few particulars from the APA requirements; they thus conform,

are subject to or will be adversely affected by the challenged pay adjustment and whether their participation would contribute "to an equitable decision." All parties granted leave to participate are allowed to present evidence and argument in writing in support of their positions. Id. \& 205.32. For the definition of pay challenge, see note 72 supra.

825 U.S.G. $\$ \S 554-57$ (1970).

83 Id. § 554(a). 
in the main, to the norms of administrative procedure that the APA has come to represent. ${ }^{84}$

\section{B. Judicial Review}

The 1971 amendments concerning judicial review of stabilization regulations and decisions ${ }^{85}$ are intended to achieve three primary ends: "(1) speed and consistency of decisions in cases arising under the Act, (2) avoidance of any breaks or stays in the operation of the Stabilization Program, and (3) relief for particular persons aggrieved by the operation of the program."86 The amendments give the federal district courts exclusive original jurisdiction over cases arising under the Act and under regulations and orders issued by the control agencies, regardless of the amount in controversy. To insure consistency of decision, the amendments create a Temporary Emergency Court of Appeals to hear all appeals from district court decisions in economic control cases. In general, the Emergency Court has the same jurisdictional powers as the circuit courts of appeals.

The amendments provide that no regulation issued by a control agency may be enjoined or set aside unless a final judgment of the Emergency Court or the Supreme Court determines that the regulation is beyond the agency's statutory authority or arbitrary and capricious. Similarly, no order or adjudication may be enjoined or set aside except when a final judgment of the Emergency Court or the Supreme Court determines that the order is beyond the agency's statutory authority, unsupported by substantial evidence, or otherwise unlawful under the judicial review criteria set forth in the Administrative Procedure Act. ${ }^{87}$ The district courts have no power to enjoin, either temporarily or permanently, the operation of any part of the control program, and the Emergency Court may issue injunctions only upon final judgment. The district courts may, however, declare a regulation or order invalid under the criteria for judicial review of agency actions described above, and any party may then, within thirty days, file a motion in the Emergency Court requesting permanent injunctive relief. There is, however, one important exception to the amendments' limitations on the availability of injunctive relief: "In order to provide relief for a particular person who may be aggrieved by the operation of this program during the period in which he is attempting to establish his legal position," both

84 See Wong Yang Sung v. McGrath, 339 U.S. 33 (1950).

851971 Amendments § 211.

86 S. REP. No. 92-507, supra note 5, at 10.

875 U.S.C. $\S 706$ (1970). 
the district courts and the Emergency Court are empowered to enjoin, either temporarily or permanently, the application of a particular order or regulation to a party in litigation before them. ${ }^{88}$

These provisions, taken together, appear to provide an efficient and thorough structure for judicial review of control agency actions. It may be questioned, however, whether the elaborate restrictions on the powers of the courts to grant preliminary injunctive relief are of any real utility. In their absence, the courts would be governed by normal equity principles-plaintiffs would have to demonstrate the probability of irreparable injury, and this probability would be balanced against possible danger to the control system and the nation's economy were injunctive relief, whether temporary or permanent, granted. ${ }^{89}$ But the statutory provision allowing individual litigants injunctive relief from the application of particular regulations and orders is a significant improvement over the President's proposals, which would have forbidden temporary injunctions altogether. ${ }^{90}$ The present control program is not intended to prevent all general price fluctuations above certain maximum levels, as were the wartime controls. Temporary price or wage increases by a particular firm, authorized by temporary injunctive relief, will not, therefore, endanger in any significant way the general effectiveness of the controls and may be able to prevent irreparable economic damage to individual parties.

\section{SUMMARY}

It has been the stated goal of the Administration from the outset of the Phase II economic control program to avoid the creation of a massive bureaucratic apparatus like those that administered the stabilization programs of World War II and the Korean conflict.91 But a control program inadequately staffed may be far more injurious to the economic health of the nation than no control program at all. The stabilization measures instituted by the Phase II control agencies attempt to regulate the general performance of the economy by placing elaborate

881971 Amendments $\S 211$ (d)(2); S. REP. No. 92-507, supra note 5, at 11-12. If the district court determines that an action commenced before it concerning economic controls raises a substantial constitutional issue, it is required to certify the issue to the Emergency Court, which may either have the entire case sent to it for decision or remand with binding instructions. $I d$. $\$ 211$ (c).

89 This point is discussed in Yakus v. United States, 321 U.S. 414, 440-42 (1944).

90 S. 2712 , 92d Cong., 1st Sess. $\S 208(\mathrm{f})-(\mathrm{g})(1971)$. On this point, the Administration bill hewed closely to the judicial review provisions of the wartime stabilization statutes. See text and note at note 29 supra.

91 See White House Background Paper, supra note 1, at 2226. See also S. REP. No. 92507, supra note 5, at 21-22 (Individual Views of Senators Proxmire, Williams, and Mondale). 
constraints on the details of daily economic transactions; they inevitably interfere with the market forces that normally govern the rise and fall of wage and price levels. This comment has attempted to demonstrate the necessity of adequate administrative and judicial review machinery and broad participation in agency decision-making processes in order to minimize this interference. The procedural regulations issued by the agencies and the judicial review structure created by Congress seem, on their face, adequate to meet this need. Of course, if the agencies should, in the future, abandon the present control scheme and adopt, in its stead, the kind of sector control employed by the wartime programs, different and perhaps more summary procedures might be appropriate. If the present control program should fail, it will not be because of some inherent incompatibility between comprehensive economic controls, on the one hand, and normal standards of procedural fairness, on the other; rather, it will be because the personnel necessary to give the procedural structure flesh are lacking or, more likely, because the substantive policies of the stabilization program are mistaken.

Ronald G. Carr 